\title{
DOCOSAHEXAENOIC ACID ADMINISTRATION AMELIORATES SCOPOLAMINE-INDUCED MEMORY IMPAIRMENT IN MICE
}

\author{
KOTHARI SAROJ, SINGHAL TULIKA*
}

\author{
Department of Pharmacology, Gajra Raja Medical College, Gwalior, Madhya Pradesh, India. Email: sdrtulika02@gmail.com
}

Received: 07 February 2018, Revised and Accepted: 22 March 2018

\begin{abstract}
Objective: The main objective of this work was to study the memory-enhancing activity of docosahexaenoic acid (DHA) supplementation in normal memory function and scopolamine-induced impaired memory in mice.
\end{abstract}

Methods: The gum acacia suspension of DHA was administered by gavage at the dose of 200 and $300 \mathrm{mg} / \mathrm{kg}$ in mice for 30 days to evaluate memoryenhancing potential on normal and scopolamine-induced impaired memory in albino mice. Escape latency in Morris water maze (MWM) and transfer latency (TL) in elevated plus maze (EPM) were recorded, respectively. Mice were given four trial sessions per day to locate the platform for 4 days in MWM model. Scopolamine $1 \mathrm{mg} / \mathrm{kg}$ was injected i.p. to produce memory impairment in mice.

Result: DHA suspension at the dose of $300 \mathrm{mg} / \mathrm{kg}$ showed significant reduction of escape latency and TL as compared to control group, and the effect was comparable to that of standard nootropic agent piracetam at the dose of $100 \mathrm{mg} / \mathrm{kg}$ in normal and scopolamine-treated mice. However, DHA at the dose of $200 \mathrm{mg} / \mathrm{kg}$ showed significant memory-enhancing effect in only scopolamine-induced impaired memory model.

Conclusion: The study revealed that the chronic administration of DHA exhibited significant memory-enhancing activity against both normal as well as scopolamine-treated impaired memory mice groups, however, this effect was more marked on scopolamine-induced memory impairment as compared to normal memory function.

Keywords: Docosahexaenoic acid, Scopolamine, Morris water maze, Elevated plus maze, Piracetam.

(C) 2018 The Authors. Published by Innovare Academic Sciences Pvt Ltd. This is an open access article under the CC BY license (http://creativecommons. org/licenses/by/4. 0/) DOI: http://dx.doi.org/10.22159/ajpcr.2018.v11i6.25187

\section{INTRODUCTION}

Learning is defined as the acquisition of information and skills and subsequent retention of that information is called memory. Learning and memory are fundamental higher brain functions that allow the individual to adapt to the environment. Learning is acquired when a stimulus or a sequence of stimuli are transmitted to the brain which is encoded into memory trace, possibly by formation of new synaptic connections in the brain areas involved in forming and storing the acquired information including hippocampus, cortex, and cerebellum [1].

The cognition refers to the process of acquiring, storing, and utilizing intellectual knowledge. Cognitive enhancers such as piracetam (PCT), oxiracetam, and aniracetam are used primarily to treat cognitive or motor function in disorders such as Alzheimer's disease, mental retardation in children, and memory impairment due to brain injury [2]. These drugs work by increasing the brain's supply of acetylcholine, increase perfusion of brain's oxygen or by activating nerve growth [3]. The main concern with these drugs is their efficacy in such clinical conditions and adverse effects [4].

Docosahexaenoic acid (DHA) (DHA, C22;6 $\omega$-3) is a long-chain polyunsaturated omega-3 fatty acid and is an integral part of neural membrane phospholipids [5]. DHA has been shown to accumulate in areas of the brain involved in memory and attention such as the cerebral cortex and hippocampus [6]. Advanced cognitive function is uniquely human and impairment of cognitive abilities affects the quality of life [7]. The use of cognition enhancers by healthy individuals in the absence of a medical indication is one of the most debated topics among neuroscientists and psychiatrists. DHA additions to various foods such as dairy products, juices, beverages, and bakery products are being tried and are available in some countries. Nonetheless, the international sales of cognition-enhancing supplements exceeded US\$1 billion in 2015, and the global demand for these compounds is still growing rapidly [8].

The effect of DHA supplementation on cognition during childhood is controversial [9]. Some studies reporting no effect [10], whereas some suggesting improvement in verbal learning and memory [11]. Therefore, the present study is planned to clearly define the role of chronic DHA supplementation in specific aspects of normal memory function and scopolamine impaired memory function in mice.

\section{MATERIALS AND METHODS}

\section{Materials}

\section{Drugs and chemicals}

DHA was purchased from Green Heaven India (A Herbal Manufacturing Unit), Nagpur, Maharashtra. Scopolamine hydrobromide (Injection Buscogast - Sovereign Pharma Pvt., Ltd.) and PCT (Tablet Nootropil Dr. Reddy's Laboratories Ltd.) were purchased from the medical store. All the drugs were administered as $2 \%$ gum acacia (GA) suspension.

\section{Animals}

Randomly bred 6-8-week-old albino male mice weighing 30-40 g, raised in the animal house of the Department of Pharmacology, Gajara Raja Medical College, Gwalior, were used for the study. These were maintained at $24+2^{\circ} \mathrm{C}$, humidity $50 \pm 5 \%$ with $12 \mathrm{~h}$ light and dark cycle and kept on standard pellet diet (Pranav Agro Industries, Delhi, India) and water ad libitum. The care and maintenance of animals was as per the approved guidelines of the Committee for the purpose of Control and Supervision of Experiments on Animals in India. The Institutional Animal Ethics Committee approved the protocol. (Registration number 846/GO/Ere/S/04/CPCSEA). 


\section{Methods}

Morris water maze (MWM)

The MWM is a white, circular pool with an inner diameter of $110 \mathrm{~cm}$ and walls $20 \mathrm{~cm}$ high. It was filled with normal tap water to a depth of $13 \mathrm{~cm}$. The water was at room temperature $\left( \pm 22^{\circ} \mathrm{C}\right)$ and made opaque by adding a small amount of milk powder with no noticeable side effects to the animals. The entire pool was divided into four quadrants of equal size by two diagonal lines running through the center of the pool. A removable circular escape platform (diameter: $10 \mathrm{~cm}$ ) positioned at the middle of a quadrant. The pool was placed at the far end of a rectangular room dimly lit by white light. The walls of the room were equipped with a variety of spatial cues which remained unchanged during the whole experiment [12].

On $26^{\text {th }}$ day of drug administration, training of mice was started. Mice were brought from their housing facility to the behavior room and were kept in an area where they cannot see the pool or spatial cues to adjust to the new environment for at least $30 \mathrm{~min}$ before testing. During the 4 subsequent days, the mice were given four trial sessions per day with the platform in place. When mice located the platform, it was permitted to remain on it for $10 \mathrm{~s}$. The escape latencies (s) to reach the platform were recorded. If the mice did not locate the platform within $120 \mathrm{~s}$, it was placed on the platform for $10 \mathrm{~s}$. The time interval between trial sessions was $30 \mathrm{~min}$. After $24 \mathrm{~h}$ learning period, mice were evaluated for retention of learning (memory). EL was recorded after $45 \mathrm{~min}$ of administration of the last dose of DHA, on $30^{\text {th }}$ day and again after $24 \mathrm{~h}$, that is, on $31^{\text {st }}$ day in normal mice. To study the effect on impaired memory, scopolamine $(1 \mathrm{mg} / \mathrm{kg})$ was injected i.p. after $45 \mathrm{~min}$ of administration of DHA or standard drugs or vehicle on the $30^{\text {th }}$ day, and EL was recorded after $45 \mathrm{~min}$ of injection of scopolamine on the $30^{\text {th }}$ day and after $24 \mathrm{~h}$.

\section{Elevated plus maze (EPM)}

The plus maze was in the shape of a cross or plus with two closed arms each with roof open measuring $30 \mathrm{~cm} \times 5 \mathrm{~cm} \times 20 \mathrm{~cm}$, extending from the central region $(5 \mathrm{~cm} \times 5 \mathrm{~cm})$ running along a North-South axis and two open arms each measuring $30 \mathrm{~cm} \times 5 \mathrm{~cm}$ running East-West. The wooden apparatus was elevated to a height of $50 \mathrm{~cm}$ from the floor in a dimly illuminated room. Animals were placed individually at the end of either of the open arms facing away from the central platform. The time taken by each animal to move from open arm to either of the closed arms was recorded. This duration of time was called transfer latency (TL). If the animal does not enter into any of the enclosed arms within $120 \mathrm{~s}$, it was gently pushed into any of the enclosed arms and TL was considered as $120 \mathrm{~s}$. Later, the animal was allowed to explore the plus maze for $5 \mathrm{~min}$ and send back to the home cage [13,14]. TL measured On $30^{\text {th }}$ day serves as a parameter or acquisition (learning), while TL on $31^{\text {st }}$ day indicates retention of learning (memory). An arm entry was defined as all four feet in the arm. The apparatus was cleaned with alcohol after each mouse was tested to remove any residue or odor.

TL was recorded after 45 min of administration of the last dose of DHA on $30^{\text {th }}$ day and again after $24 \mathrm{~h}$, that is, on $31^{\text {st }}$ day in normal mice. To study the effect on impaired memory, scopolamine (1 mg/kg) was injected i.p. after 45 min of administration of DHA or standard drugs or vehicle on $30^{\text {th }}$ day and TL was recorded after 45 min of injection of scopolamine on $30^{\text {th }}$ day and after $24 \mathrm{~h}$.

\section{Study design}

To ensure consistency of experience before the test session, animals were brought to the testing room $1 \mathrm{~h}$ before the start of behavior testing. Test room lighting, temperature, and noise level were kept constant for all mice used in the study. DHA or standard drugs were given for 30 days. Dose of DHA was chosen on the basis of the previous study done to see effect of DHA.

To study the effect on normal memory using MWM and EPM model mice were divided into four groups having six animals in each group as follows:
- Group1: Control received 2\% GA at the dose of $10 \mathrm{ml} / \mathrm{kg}$

- Groups 2 and 3: Test drug-treated group received DHA $200 \mathrm{mg} / \mathrm{kg}$ and DHA $300 \mathrm{mg} / \mathrm{kg}$ respectively

- Group 4: Standard drug-treated group received PCT 100 mg/kg

To study the effect on impaired memory using MWM and EPM model mice were divided into five groups having six animals in each group.

- Group 1: Normal control received 2\% GA at the dose of $10 \mathrm{ml} / \mathrm{kg}$

- Group 2: Negative control received 2\% scopolamine $1 \mathrm{mg} / \mathrm{kg}$

- Groups 3 and 4: Drug-treated group received scopolamine $1 \mathrm{mg} /$ $\mathrm{kg}+$ DHA $200 \mathrm{mg} / \mathrm{kg}$ and scopolamine $1 \mathrm{mg} / \mathrm{kg}+$ DHA $300 \mathrm{mg} / \mathrm{kg}$, respectively

- Group 5: Standard drug-treated group received scopolamine1 mg/ $\mathrm{kg}+$ PCT $100 \mathrm{mg} / \mathrm{kg}$.

\section{Statistical analysis}

Statistical evaluation was done using one-way ANOVA followed by Tukey's multiple comparison tests. $\mathrm{p}<0.05$ were considered statistically significant. Data were presented as mean + standard error of the mean. All statistical analysis was performed by Sigma Stat software version 2.0, Jandel Scientific Inc. USA.

\section{RESULTS}

\section{Effect of DHA on normal memory}

EL and TL of the $30^{\text {th }}$ day of drugs treatment reflected learning behavior of animals, whereas TL and EL on the $31^{\text {st }}$ day reflected retention of learned task as memory. Administration of DHA at the dose of $200 \mathrm{mg} / \mathrm{kg}$ decreased escape latency by $16 \%$ and TL by $6 \%$ in MWM, respectively, and was statistically not significant ( $p>0.05)$ as compared to control. DHA at the dose of $300 \mathrm{mg} / \mathrm{kg}$ decreased escape latency by $39 \%$, TL by $45 \%$ in MWM and EPM, respectively, and was statistically significant $(\mathrm{p}<0.05)$ as compared to control and DHA $200 \mathrm{mg} / \mathrm{kg}$ suggesting memory-enhancing effect. PCT decreased escape latency by $51 \%$ and TL by $54 \%$ in MWM and EPM, respectively, and was significant $(\mathrm{p}<0.05)$ as compared to control and DHA $200 \mathrm{mg} / \mathrm{kg}$ Effect of DHA $300 \mathrm{mg} / \mathrm{kg}$ was comparable to PCT (Tables 1 and 2).

\section{Effect of DHA on impaired memory}

Administration of scopolamine $1 \mathrm{mg} / \mathrm{kg}$ increased escape latency by $46 \%$ in MWM and TL by $94 \%$ in EPM as compared to normal control group and was statistically significant $(\mathrm{p}<0.05)$ demonstrating memory impairment. Administration of DHA at the dose of $200 \mathrm{mg} / \mathrm{kg}$ in scopolamine-treated animals decreased escape latency by $30 \%$ and TL by $23 \%$ in MWM and EPM, respectively, and was statistically significant $(\mathrm{p}<0.05)$ as compared to negative control suggesting cognitiveenhancing effect. DHA at the dose of $300 \mathrm{mg} / \mathrm{kg}$ in scopolamine-treated group decreased escape latency by $39 \%$, TL by $42 \%$ in MWM and EPM, respectively, and was statistically significant $(\mathrm{p}<0.05)$ as compared to negative control suggesting improvement in memory. Administration of PCT in scopolamine-treated animals decreased escape latency by $57 \%$ and TL by $51 \%$ in MWM and EPM, respectively, and was significant $(\mathrm{p}<0.05)$ as compared to negative control and DHA $200 \mathrm{mg} / \mathrm{kg}$. Effect of DHA $300 \mathrm{mg} / \mathrm{kg}$ was comparable to PCT (Figs. 1 and 2).

\section{DISCUSSION}

Memory is divided into two general types, declarative and nondeclarative. Declarative memory relates to the conscious recollection of facts and events and can be further subdivided into episodic and semantic. Episodic memory is memory for personally experienced events that occur at a specific place and time and is measured by memory of stories, word lists, or figures [15]. In the present investigation, effect of chronic administration of DHA was studied on learning and memory of normal and scopolamine-treated mice.

The MWM was described 30 years ago as a device to investigate spatial learning and memory in laboratory rats. Spatial learning in general and MWM performance, in particular appear to depend on the coordinated action of different brain regions and neurotransmitter 
Table 1: Effect of DHA on escape latency using MWM in normal mice

\begin{tabular}{lll}
\hline Treatment & \multicolumn{2}{c}{ Mean escape latency $(\mathbf{s})$} \\
\cline { 2 - 3 } & On $\mathbf{3 0}^{\text {th }}$ day & On 31 $^{\text {st }}$ day \\
\hline GA10 & $66.83 \pm 2.47$ & $65.17 \pm 2.75$ \\
DHA200 & $59.50 \pm 9.23$ & $55.17 \pm 4.38$ \\
DHA300 & $54.33 \pm 2.91$ & $39.67 \pm 1.26^{\text {*\# }}$ \\
PCT100 & $50.33 \pm 5.19$ & $32.00 \pm 2.46^{\text {*\# }}$
\end{tabular}

GA10: Gum acacia $10 \mathrm{ml} / \mathrm{kg}$, DHA200: Docosahexaenoic acid $200 \mathrm{mg} / \mathrm{kg}$, DHA300: Docosahexaenoic acid 300 mg/kg, PCT100: Piracetam $100 \mathrm{mg} / \mathrm{kg}$ $\mathrm{n}=6$ animals in each group. Values are expressed as mean \pm SEM, ${ }^{*} \mathrm{p}<0.05$ as compared to GA10, $\#$ p $<0.01$ as compared to DHA200. SEM: Standard error of the mean

Table 2: Effect of DHA on TL using elevated plus-maze in normal mice

\begin{tabular}{lll}
\hline Treatment & Mean TL (s) & \\
\cline { 2 - 3 } & On $\mathbf{3 0}^{\text {th }}$ day & On $\mathbf{3 1}^{\text {st }}$ day \\
\hline GA10 & $29.50 \pm 3.28$ & $26.33 \pm 3.77$ \\
DHA200 & $27.50 \pm 3.92$ & $24.83 \pm 1.67$ \\
DHA300 & $22.83 \pm 3.72$ & $14.50 \pm 1.40^{*} \#$ \\
PCT100 & $19.33 \pm 3.68$ & $12.33 \pm 1.02^{*} \#$
\end{tabular}

GA10: Gum acacia $10 \mathrm{ml} / \mathrm{kg}$, DHA200: Docosahexaenoic acid $200 \mathrm{mg} / \mathrm{kg}$ DHA300: Docosahexaenoic acid $300 \mathrm{mg} / \mathrm{kg}$, PCT100: Piracetam $100 \mathrm{mg} / \mathrm{kg}$ $\mathrm{n}=6$ in each group. Values are expressed as mean $\pm S E M,{ }^{*} \mathrm{p}<0.01$ as compared to GA10, ${ }^{*} \mathrm{p}<0.05$ as compared to DHA200 group. SEM: Standard error of the mean

systems constituting a functionally integrated neural network. MWM task has often been used in the validation of rodent models for neurocognitive disorders and the evaluation of possible neurocognitive treatments [16].

EPM served as the exteroceptive behavioral model to evaluate memory in rats. The spontaneous alteration in behavior in the EPM is considered to reflect working memory. Based on the natural aversion of mice of high and open spaces reported that TL (the time in which mouse moves from the open arms to the enclosed arm) on the $2^{\text {nd }}$ day onward was shortened than on the $1^{\text {st }}$ day and suggested that this shortened TL can be utilized as a parameter for learning and memory [17].

In the present study, chronic administration of DHA in normal mice significantly decreased escape latency in MWM and TL in EPM suggesting enhancement in memory. Improved spatial learning performance due to DHA may be associated with enhanced neurogenesis as reported in earlier studies $[18,19]$. The hippocampus, in particular, is essential for memory function. DHA promotes hippocampal neuronal development and synaptic function [20] contributing to improvements in the performance of memory-related tasks such as the MWM [21]. On the other hand, dietary deficiency of $\mathrm{n} 3$ fatty acid demonstrated moderate impairment of Barnes maze performance compared with $\mathrm{n} 3$ fatty acid adequate rats [22].

In the second part of the present study, chronic administration of DHA significantly reversed scopolamine-induced increased escape latency to reach the platform in MWM and TL in EPM, respectively, suggesting spatial memory-enhancing effect.

Memory impairment in the scopolamine-induced animal model is associated with increased oxidative stress [23,24]. Oxidative stress is well known to impair learning and memory leading to cognitive dysfunction [25]. Cognitive-enhancing effect of DHA in scopolamineinduced memory impairment in the present study could be due to the free-radical scavenging property of DHA [26]. Oral administration

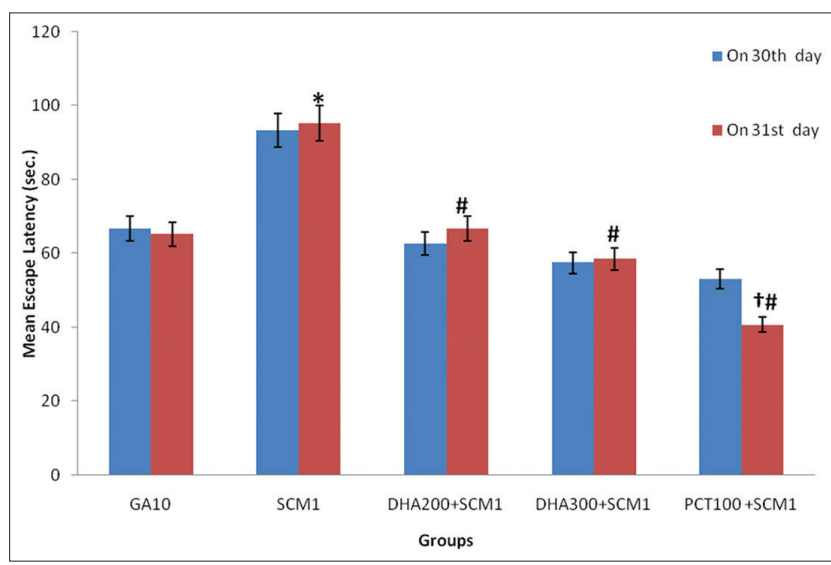

Fig. 1: Bar diagram showing increased escape latency following scopolamine and ameliorative action of docosahexaenoic acid (DHA) $(200$ and $300 \mathrm{mg} / \mathrm{kg})$ and piracetam on escape latency in scopolamine-treated mice using Morris water maze. Each column represents mean \pm standard error of the mean, $n=6$ mice in each group. ${ }^{*} \mathbf{p}<0.01$ as compared to gum acacia 10 (normal control),,$p<0.01$ as compared to SCM1 (negative control), ${ }^{\dagger} p<0.01$ as compared to DHA200+SCM1 group

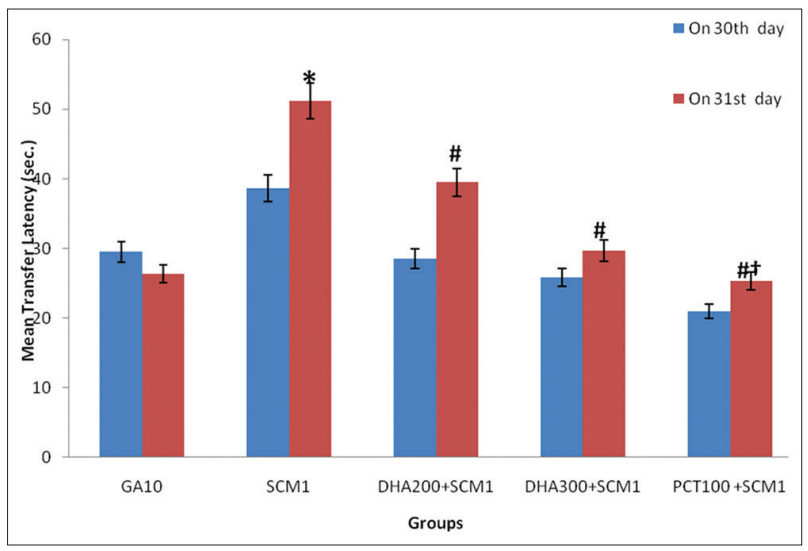

Fig. 2: Bar diagram showing increased transfer latency

(TL) following scopolamine and ameliorative action of docosahexaenoic acid (DHA) $(200$ and $300 \mathrm{mg} / \mathrm{kg})$ and piracetam on TL in scopolamine-treated mice using elevated plus maze.

Each column represents mean \pm standard error of the mean, $n=6$ mice in each group $* \mathbf{p}<0.01$ as compared to gum acacia 10 (normal control),,$p<0.05$ as compared to SCM1 (negative control), ${ }^{\dagger} \mathbf{p}<0.05$ as compared to DHA200+SCM1 group

of DHA is accompanied with an increased activity of catalase and glutathione peroxidase enzymes [27].

\section{CONCLUSION}

Thus, the data of the present study support cognitive-enhancing effect of chronic DHA intake in normal and impaired memory mice, however, the memory-enhancing effect of DHA is more marked in scopolamineinduced memory impairment as compared to normal memory function. Long-term interventional studies are required to know the exact mechanism of cognitive enhancing effect of DHA.

\section{ACKNOWLEDGMENTS}

The authors are thankful to Dr. S.N. Iyenger, Dean Gajra Raja Medical College, Gwalior, for his encouragement to do research work.

\section{AUTHORS CONTRIBUTIONS}

Equally contributed. 


\section{CONFLICTS OF INTERESTS}

Declared none.

\section{REFERENCES}

1. Chen KH, Chuah LY, Sim SK, Chee MW. Hippocampal region-specific contributions to memory performance in normal elderly. Brain Cogn 2010;72:400-7.

2. Schever K, Rostock A, Bartsch P, Muller WK. Piracetam improved cognitive performance by restoring neurochemical deficits of the aged rat brain. Pharmacopsychiatry 1999;32:10-60.

3. Kamila S, Madhav NS, Sarkar C. Safety and efficacy study of herbal polyphyto formulations: For its learning and memory enhancing properties. Int J Pharm Pharm Sci 2016;8:119-23.

4. Colucci L, Bosco M, Ziello AR, Rea R, Amenta F, Fasanaro AM. Effectiveness of nootropic drugs with cholinergic activity in treatment of cognitive deficit: a review. J Exp Pharmacol 2012;4:163.

5. Anderson GJ, Connor WE, Corliss JD. Docosahexaenoic acid is the preferred dietary n-3 fatty acid for the development of the brain and retina. Pediatr Res 1990;27:89-97.

6. Guesnet P, Alessandri JM. Docosahexaenoic acid (DHA) and the developing central nervous system (CNS)-Implications for dietary recommendations. Biochimie 2011;93:7-12.

7. Weiser MJ, Butt CM, Mohajeri MH. Docosahexaenoic acid and cognition throughout the lifespan. Nutrients 2016;8:99.

8. Tarfarosh SF, Tromboo U, Bhat F. Search for a perfect Nootropic supplement combination-Can we increase human intelligence by nutritional supplements. J Pharmacogn Phytochem 2017;6:1020-4.

9. Harmita H, Mansur U, Stephanie S. Determination of docosahexaenoic acid in infant formulas with gas chromatography. Asian J Pharm Clin Res 2018;11:247-250

10. Osendarp SJ, Baghurst KI, Bryan J, Calvaresi E, Hughes D, Hussaini MK, et al. Effect of a 12-mo micronutrient intervention on learning and memory in well-nourished and marginally nourished school-aged children: 2 parallel, randomized, placebo-controlled studies in Australia and Indonesia. Am J Clin Nutr 2007;86:1082-93.

11. Dalton A, Wolmarans P, Witthuhn RC, Stuijvenberg ME, Swanevelder SA, Smuts CM. A randomised control trial in schoolchildren showed improvement in cognitive function after consuming a bread spread, containing fish flour from a marine source. Prostaglandins Leukot Essent Fat Acids 2009;80:143-9.

12. D'Hooge R, De Deyn PP. Applications of the Morris water maze in the study of learning and memory. Brain Res Rev 2001;36:60-90.

13. De Bruin JP, Sanchez-Santed F, Heinsbroek RP, Donker A, Postmes P. A behavioural analysis of rats with damage to the medial prefrontal cortex using the Morris water maze: Evidence for behavioural flexibility, but not for impaired spatial navigation. Brain Res 1994;652:323-33.

14. Holguin S, Huang Y, Liu J, Wurtman R. Chronic administration of DHA and UMP improves the impaired memory of environmentally impoverished rats. Behav Brain Res 2008;191:11-6.

15. Budson AE, Price BH. Memory: Clinical Disorders. Encyclopedia of Life Sciences. London: Nature Publishing Group; 2001. p. 1-8.

16. Bromley-Brits K, Deng Y, Song W. Morris water maze test for learning and memory deficits in Alzheimer's disease model mice. J Vis Exp 2011;53:2920.

17. Nade VS, Kawale LA, Valte KD, Shendye NV. Cognitive enhancing effect of angiotensin-converting enzyme inhibitors and angiotensin receptor blockers on learning and memory. Ind $\mathrm{J}$ Pharmacol 2015;47:263.

18. He C, Qu X, Cui L, Wang J, Kang JX. Improved spatial learning performance of fat- 1 mice is associated with enhanced neurogenesis and neuritogenesis by docosahexaenoic acid. Proc Natl Acad Sci U. S. A 2009; 106:11370-5.

19. Titova OE, Sjögren P, Brooks SJ, Kullberg J, Ax E, Kilander L, et al. Dietary intake of eicosapentaenoic and docosahexaenoic acids is linked to gray matter volume and cognitive function in elderly. Age 2013;35:1495-505.

20. Cao D, Kevala K, Kim J, Moon HS, Jun SB, Lovinger D, et al. Docosahexaenoic acid promotes hippocampal neuronal development and synaptic function. J Neuro Chem 2009;111:510-21.

21. Awakita E, Hashimoto M, Shido O. Docosahexaenoic acid promotes neurogenesis in vitro and in vivo. Neuroscience 2006;139:991-7.

22. Fedorova I, Hussein N, Baumann MH, Di Martino C, Salem NA. n-3 fatty acid deficiency impairs rat spatial learning in the Barnes maze. J Behav Neurosci 2009;123:196-205.

23. El-Sherbiny DA, Khalifa AE, Attia AS, Eldenshary Eel-D. Hypericum perforatum extract demonstrates antioxidant properties against elevated rat brain oxidative status induced by amnestic dose of scopolamine. Pharmacol Biochem Behav 2003;76:525-33.

24. Kulkarni KS, Kasture SB, Mengi SA. Efficacy study of Prunus amygdalus (almond) nuts in scopolamine-induced amnesia in rats. Ind J Pharmacol 2010;42:168.

25. Deka P, Kumar A. Pharmacological evaluation of Triphala churna instreptozotocin (i. C. V.) Induced dementia in rats. Int J Pharm Pharm Sci 2018;10:97-105.

26. Kim YJ, Chung HY. Antioxidative and anti-inflammatory actions of docosahexaenoic acid and eicosapentaenoic acid in renal epithelial cells and macrophages. J Med Food 2007;10:225-31.

27. Casanas-Sänchez V, Perez JA, Fabelo N, Alemany DQ, Diaz ML. Docosahexaenoic (DHA) modulates phospholipid-hydroperoxide glutathione peroxidase $(\mathrm{Gpx} 4)$ gene expression to ensure self-protection from oxidative damage in hippocampal cells. Front Physiol 2015;6:203. 